\title{
Editorial
}

http://dx.doi.org/10.14483/calj.v18n2.aa00

\section{Self-study research in teacher education}

Studies about teacher learning during the last twenty years have focused on the relationship between knowledge and practice. Cochran-Smith and Lytle (1999), situate self-study in the category of knowledge-of-practice and propose a view of inquiry as stance to understand teaching and learning about practice as a process that occurs during the span of a teacher's career. Self-study research is a fairly new approach to teacher research that views teachers as reflective practitioners and focuses on the critical examination of one's own practice.

The literature on self-study research provides contributions from Dinkelman (2003), Loughran (2007), Cochran-Smith and Lytle (1999), Clandinin and Connelly (2007), and Peercy (2014), among others. Loughran (2007) defends that a central purpose in self-study is uncovering deeper understandings of the relationship between teaching about teaching and learning about teaching. Connelly and Clandinin, (2007, p. 575) distinguish between teachers' knowledge as something they possess and a view of knowledge as coming from their practices. They consider that self-study is important because of its potential to reveal knowledge of the educational landscape. Dinkleman defines self-study as "intentional and systematic inquiry into one's own practice" (p. 8). Lastly, Peercy (2014) uses self-study as a mechanism for innovation and change within a framework of practice-based education in teacher education.

From my experience as teacher educator learning from teachers and doing research with teachers, I see the value of self-study when teachers see what they know through reflections about their practice. In our latest collaborative project using community-based pedagogies with teachers in public schools in Bogotá, (Sharkey, Clavijo-Olarte, E Ramirez, 2016), we saw teachers surprised of what they knew and didn't know about their students' community in relation to their teaching in classrooms. This work showed a self-discovery feature of self-study that was important when engaging with others in inquiries in their own schools. Thus, teachers' rich stories emerged from 20 and 30 years of experience working in the same community and not knowing much about it. Our collaborative work between university and schools, teacher educators and practicing teachers, and between researchers to plan community inquiries using teachers' knowledge of practice, different content areas, the physical context, families, and the communities highlights the richness of teachers' narratives.

But the question remains of how to do self-study and what is used in self-study research? In self-study, researchers use teachers' autobiographies, personal-experience methods, teachers' narratives of their own practice, teachers' own teaching journals, and personal history-based beliefs relevant in teacher decision making to understand teachers' stories. The words of a teacher educator and experienced researcher, Theresa Austin (2016), help me better illustrate self-study research in teacher education. She defined self-study as "revolutionary in the sense that it includes the researcher as object of investigation and in so doing it helps him/her to be conscious about the process of research as well as the results. Self-study research is done with a critical lens, and in an equitable mode as it shares the power position of research with those participating in it. There is no way to become the invisible researcher neither the omnipotent one." (Personal communication, July, 2016). 
All in all, and resorting to an ongoing conversation with my Chilean colleague Miguel Farías, we believe that by focusing our awareness on our own teaching and learning practices and sharing the results of such observations in collaborative communities of interest, language educators are furnished with robust critical and contextualized views of the learning process. Such self-mirrorings may challenge inherited beliefs on the status of knowledge and practice in our disciplinary fields but, consequently, they open new avenues to our understanding of the marvelous world of language learning.

\section{References}

Cochran-Smith, M., \& Lytle, S. L. (1999). Relationships of knowledge and practice: Teacher learning in communities. Review of Research in Education, 24, 249-305.

Clandinin, D. J., \& Connelly, M. (2007). Knowledge, narrative and self-study. In J. J. Loughran, M. L. Hamilton, V. K. LaBoskey, \& T. Russell (Eds.), International handbook of self-study of teacher and teacher education practices (pp. 575-600). The Netherlands: Springer.

Dinkleman, T. (2003). Self-study in teacher education: A means and ends tool for promoting reflective teaching. Journal of Teacher Education, 54(1), 6-18.

Loughran. J. (2007) Researching teacher education practices: Responding to the challenges, demands, and expectations of self-study. Journal of Teacher Education, (58)1, 12-20.

Peercy, M. (2014). Challenges in enacting core practices in language teacher education: A self-study. Studying Teacher Education: A Journal of Self-Study of Teacher Education Practices, 10(2), 146-162.

Samaras, A. P. (2002). Self-study for teacher educators: Crafting a pedagogy for educational change. NY: Peter Lang

Sharkey, J., Clavijo-Olarte, A., E Ramirez, M. (2016). Developing a Deeper Understanding of Community-Based Pedagogies with Teachers. Learning With and From Teachers in Colombia. Journal of Teacher Education, 67(4), 1-14.

Amparo Clavijo Olarte PhD

Editor 


\section{Editorial}

\section{El auto estudio como enfoque de investigación en la formación docente}

Estudios sobre el aprendizaje de los docentes durante los últimos veinte años se han centrado en la relación entre conocimiento y práctica. Cochran-Smith y Lytle (1999), sitúan el autoestudio en la categoría de conocimiento de prácticas y proponen una mirada de la indagación como postura para entender la práctica de enseñanza y aprendizaje como un proceso que ocurre a lo largo de la carrera de un profesor. La investigación de auto-estudio es un enfoque relativamente nuevo en la investigación docente que, considera a los profesores como profesionales reflexivos y se centra en el examen crítico de la propia práctica.

La literatura sobre la investigación de auto-estudio recoge los aportes de Dinkelman (2003), (2007), Loughran Cochran-Smith y Lytle (1999), Clandinin y Connelly (2007) y Peercy (2014), entre otros. Loughran (2007) sostiene que un propósito central del auto-estudio es revelar una comprensión más profunda de la relación entre la enseñanza acerca de la enseñanza y el aprendizaje sobre la enseñanza. Connelly y Clandinin, (2007, pág. 575) distinguen entre el conocimiento de los docentes como algo que poseen y el conocimiento que deriva de sus prácticas. Estos autores consideran que el auto-estudio es importante debido a su potencial para revelar el conocimiento del panorama educativo. Dinkleman define el auto-estudio como "la investigación intencionada y sistemática de la propia práctica" (p. 8). Por último, Peercy (2014) utiliza el auto-estudio como un mecanismo para la innovación y el cambio dentro de un marco de práctica educativa basada en la formación docente.

Desde mi experiencia como docente formadora de docentes, aprendiendo de los docentes $\mathrm{y}$, haciendo investigación con los docentes, observo el valor del auto-estudio cuando los docentes pueden ver lo que saben a través de las reflexiones que hacen de su práctica. En nuestro último proyecto colaborativo, utilizando pedagogías basadas en comunidad con docentes de colegios públicos de Bogotá, (Sharkey, Clavijo-Olarte, E Ramírez, 2016), vimos docentes sorprendidos de lo que sabían y no sabían sobre la comunidad de sus estudiantes en relación con su enseñanza en las aulas. Este trabajo mostró auto-descubrimiento, característica del auto-estudio que fue importante a la hora de interactuar con otros sobre sus propias indagaciones en sus escuelas. En consecuencia, de los docentes emergieron ricas historias de 20 y 30 años de experiencia trabajando en la misma comunidad, sin saber mucho de ella. Nuestro trabajo colaborativo entre universidad y escuela, entre formadores de docentes, docentes en ejercicio e investigadores, utilizando el saber de los docentes sobre su práctica, el contenido, el contexto físico, las familias y las comunidades, pone de relieve la riqueza de las narraciones de los docentes.

Pero la cuestión se sostiene en el siguiente interrogante cंcómo hacer el auto-estudio y qué es lo que se utiliza de la investigación de auto-estudio? En el auto-estudio, los investigadores utilizan autobiografías de los docentes, métodos de experiencia personal, narrativas docentes de sus propias prácticas, diarios de campo y las creencias de los docentes, basadas en antecedentes personales; relevantes en la toma de decisiones para comprender los relatos de los docentes. Las palabras de una formadora de docentes e investigadora experimentada, Theresa Austin (2016), me ayudan a comprender mejor la investigación de auto-estudio en la formación de docentes. Ella define al auto-estudio como "revolucionario en el sentido de que incluye al investigador como objeto de investigación y, al hacerlo lo ayuda a ser consciente del proceso de investigación, así como de los resultados. La investigación de auto-estudio se realiza con un lente crítico, y en un modo equitativo, ya que comparte la posición de poder del 
investigador con los que participan en ella. No hay manera de convertirse en el investigador invisible ni en el omnipotente." (Comunicación personal, Julio, 2016).

En todo caso, recurriendo a una conversación con mi colega chileno Miguel Farías, creemos que al focalizar nuestra conciencia sobre nuestras propias prácticas de enseñanza y aprendizaje y, al compartir los resultados de tales observaciones en colaboración con comunidades de interés, los educadores de lengua están equipándose con sólidas críticas y contextualizadas opiniones del proceso de aprendizaje. Tales autorreflexiones pueden cuestionar creencias heredadas sobre el estatus de los conocimientos y la práctica en nuestros campos disciplinares, pero, consecuentemente, abren nuevas vías a nuestro entendimiento del maravilloso mundo del aprendizaje de idiomas.

\section{Referencias}

Cochran-Smith, M., \& Lytle, S. L. (1999). Relationships of knowledge and practice: Teacher learning in communities. Review of Research in Education, 24, 249-305.

Clandinin, D. J., \& Connelly, M. (2007). Knowledge, narrative and self-study. In J. J. Loughran, M. L. Hamilton, V. K. LaBoskey, \& T. Russell (Eds.), International handbook of self-study of teacher and teacher education practices (pp. 575-600). The Netherlands: Springer.

Dinkleman, T. (2003). Self-study in teacher education: A means and ends tool for promoting reflective teaching. Journal of Teacher Education, 54(1), 6-18.

Loughran. J. (2007) Researching teacher education practices: Responding to the challenges, demands, and expectations of self-study. Journal of Teacher Education, (58)1, 12-20.

Peercy, M. (2014). Challenges in enacting core practices in language teacher education: A self-study. Studying Teacher Education: A Journal of Self-Study of Teacher Education Practices, 10(2), 146-162.

Samaras, A. P. (2002). Self-study for teacher educators: Crafting a pedagogy for educational change. NY: Peter Lang

Sharkey, J., Clavijo-Olarte, A., \& Ramirez, M. (2016). Developing a Deeper Understanding of Community-Based Pedagogies with Teachers. Learning With and From Teachers in Colombia. Journal of Teacher Education, 67(4), 1-14.

Amparo Clavijo Olarte PhD

Editora 